\title{
Effects of Atlantic Ocean Encroachment on Limited Arable Land in Escravos Metropolis, Delta State, Nigeria
}

\author{
J. I. Kperegbeyi, E. Ogboi \\ Department of Agricultural Technology, School of Agriculture, Delta State Polytechnic, Ozoro, Nigeria \\ Email: jameslovekperegbeyi@gmail.com, james kperegbeyi@yahoo.com
}

Received 18 July 2015; accepted 7 August 2015; published 10 August 2015

Copyright (C) 2015 by authors and OALib.

This work is licensed under the Creative Commons Attribution International License (CC BY).

http://creativecommons.org/licenses/by/4.0/

(c) (i) Open Access

\section{Abstract}

The primary objective of the research was to assess the impact of Atlantic Ocean on limited arable land on the inhabitants of Escravos metropolis in Warri South-West Local Government Area (LGA), Delta State. The primary data used for the investigation were obtained using structured questionnaire given to 140 respondents. Anthropological methods of data collected (participants, observation) were also employed. Simple statistical tools (percentage) were used to analyze the acquired data. The result showed that $100 \%$ of the respondents opined that Atlantic Ocean encroachment (land degradation) was one of the major causes of limited arable land. While a mean of $65 \%$ of the respondents claimed that pollution of land due to crude oil exploration also caused limited arable land $46.67 \%$ mean of the respondent claimed that oil companies occupy the large available arable land for operational base and flow stations. The results also show that the impacts of Atlantic Ocean encroachment on limited arable land in Escravos metropolis resulted to a mean of $74.29 \%$ of unemployment in the host communities, which causes youth restiveness, oil bunkering and pipeline vandalization in Escravos metropolis. $60 \%$ of the respondents have migrated to urban centers as a result of scarcity of foodstuffs, high cost of agricultural products and by-products and low productivity of fishes in the area.

\section{Keywords}

Arable Land, Impact, Inhabitants, Encroachment, Salinity, Migration

Subject Areas: Agricultural Science, Environmental Sciences

\section{Introduction}

There has been an increased interest in recent years for the coastal people in Nigeria to go into arable farming, as persistent living in tropical mangrove swamps vegetation resulted to lack of farming land, which has been the 
cause of famine in the coastal region. The little available land had been used for rural settlement. Therefore, the need to establish an arable land in Escravos metropolis of Delta State is one of the dominant issues in Nigeria. A considerable number of factors are involved in land establishment which are both complex in themselves as well as their inter-relationships. [1] ascertains that this factor can be analyzed and discussed from many disciplinary and ideological perspectives and at different theoretical and analytical levels.

There are currently large and growing problems of land degradation, soil impoverishment, oil spillage, sea flooding and lowered productivity and yields in many parts of coastal regions of Southern Nigeria [2] [3]. Increased in population growth, limited arable land, inadequate agricultural produce and related pressures on natural resources have been contributing to the environmental stress through the process of oil exploration and exploitation [4]-[6].

It has been observed that limited arable land often impedes the interest of the inhabitants and oil company services in this region to go into agricultural production and hence the oil company operating in their areas to supply all their basic needs of life failure to fulfill the community's demands usually result to youth "restiveness". In comparison, the upland dwellers of oil producing communities in other Local Government Areas of Delta State do not experience limited arable land for cultivations of crops and livestock management. Therefore, such youth "restiveness" with Oil Company operating in the land is very limited. Even the State Government, Oil Company and Non-Governmental Organizations (NGOs) assist them with farm inputs of adequate quantities [7].

Most of the land that would have been used for Agriculture has been over taken by Atlantic Ocean as a result of encroachment. Ocean encroachment is the spreading of ocean like features into the land [8].

In the coastal region, limited ecological studies have been under taken to access the availability of arable land to coastal people and hence their level of willingness to be fully involved in agricultural activities for their livelihood and its impacts on the inhabitants of the oil producing communities in the coastal areas is lacking or limited Hence, to fully understand the impacts of ocean encroachment on limited arable land and inhabitants of the coastal region necessitated this work. Therefore, the main objective of this work is to assess the impact of Atlantic Ocean encroachment on limited arable land in Escravos metropolis of Warri South-West Local Government Area, Delta State.

\section{Methodology}

The study area was Warri South-West Local Government Area of Delta State, which was located between latitudes $5^{\circ} 20^{\prime} \mathrm{N}$ and $5^{\circ} 51^{\prime} \mathrm{N}$ of the Equator and between longitude $5^{\circ} 05^{\prime} \mathrm{E}$ and $5^{\circ} 47^{\prime} \mathrm{E}$ of the Greenwich meridian. The study area is about 1856 square kilometers in size with a population of 146,536 [9].

The topology of the area can be described according to [10] as swampy and water logged and the soil is allomorphic. The area is underlain by cretaceous sandstones. The typical vegetation is made up of mangrove plants of different species (red and white mangrove). The climate of the area and the soil favor the growth of mangrove trees [10]. The study area is characterized by tropical wet and dry seasons with constant wind and waves from the Atlantic Ocean. The inhabitants of the areas are Itsekiri and Ijaw tribe, and settlement in the area include Ugborodo (Escravos), Ogidigben, Ajudiabo, Madangho, Ugbegunguin, Abiteye, Benikrukru, Sahara, Opraja, Omaidino, Obobi, Olobe, Katu, Orere, Ijaghala and Oturmara.

The data used for this study were derived from primary sources. The primary data were gathered through the administration of questionnaire designed for preliminary survey of the study area. There are seven oil producing communities in the study area including Ugborodo (Escravos), Ogidigben (Headquarters), Ugbegungun, Abiteye, Otumara, Olobe and Omadino. In each, four settlements were randomly selected, thereby totaling twenty-eight settlements in all. In administering the questionnaire, stratified random sampling method was used.

Thus, it was assumed that similar problems will be faced by coastal inhabitants in the same region and that they will most likely proffer the same set of solutions. Five respondents were randomly selected from the set of aged coastal dwellers in each of the sampled settlements. A total of one hundred and forty respondents were then contacted on their residence and the place of their daily job. In other words, an important anthropological method of data collection (participant observation) was also employed; simple statistical tool (percentage) was used on analyzing the acquired data. 


\section{Results and Discussion}

Table 1 showed that most of the coastal inhabitants are farmers of both male and female with a percentage of $70.71 \%$ representing the males and $29.29 \%$ of females. This means that the male are more into farming than the females. $74.28 \%$ of the sampled farmers were between the age brackets of 40 - 60 years. This shows that majority of the sampled farmers were middle-age. It implies that they are still in their economic active age which could result in a positive effect on agricultural production. Furthermore, 85\% of the sampled respondents have one form of formal education or another. This indicates that the people of the area are literates, a fact which was assumed to have influence on their awareness of re-creation of arable land. Most of the farmers, 32.14\% have been in farming for between 31 - 40 years.

Table 1. Socio-economic characteristics of the respondents.

\begin{tabular}{|c|c|c|}
\hline Variables & Respondents $\mathrm{n}=140$ & Percentage \\
\hline \multicolumn{3}{|l|}{ Age in Years } \\
\hline $41-50$ & 46 & 32.86 \\
\hline $51-60$ & 58 & 41.42 \\
\hline $61-70$ & 32 & 22.86 \\
\hline 71 land above & 4 & 2.86 \\
\hline \multicolumn{3}{|l|}{ Sex } \\
\hline Male & 99 & $70-7 \mathrm{~J}$ \\
\hline Female & 41 & 205 \\
\hline \multicolumn{3}{|l|}{ Level of Education } \\
\hline Non-Formal & 21 & 15.00 \\
\hline Primary & 29 & 20.71 \\
\hline Secondary & 6.4 & 45.71 \\
\hline Tertiary & 26 & 18.58 \\
\hline \multicolumn{3}{|l|}{ Years of Farming Experience } \\
\hline $0-10$ & 11 & 7.8 \\
\hline $11-20$ & 18 & 12.86 \\
\hline 2130 & 34 & 24.28 \\
\hline $31^{\wedge} 0$ & 45 & 32.14 \\
\hline 4 land above & 32 & 22.86 \\
\hline \multicolumn{3}{|l|}{ Occupation } \\
\hline Fish Farming & 67 & 47.86 \\
\hline Trading & 21 & 15.00 \\
\hline Transportation & 39 & 27.28 \\
\hline Casual Worker in Oil Firm & 13 & 928 \\
\hline \multicolumn{3}{|l|}{ Household Size } \\
\hline $1-5$ & 40 & 28.57 \\
\hline $6-10$ & 70 & 50.00 \\
\hline $11-15$ & 30 & 21.43 \\
\hline
\end{tabular}

Source: Field survey, (2013). 
This means that they must have acquired good experience in the production of fish, as fish farming is the major occupation of the coastal inhabitants with $47.86 \%$ of the respondents are full-time fish farmers while the remaining $52.14 \%$ engaging in small arable crop farming and other economic activities such as water transportation, trading and casual workers to the oil firm operating in the land. All the farmers $(100 \%)$ interviewed are married. The household sizes are large, majority of them have between 6 - 15 members (71.43\%). These large families explain why most of the farmers use family labour. The study also reveals that apart from fish farming, there are backyard agricultural crop practices by the coastal people. Crop and vegetable grown in the study area include maize, sweet potatoes, cassava, yam, waterleaf, pumpkin and green vegetable.

A large percentage of respondents (86.5\%) agreed that limited arable land have hindered them to go into cultivation of arable crops while $13.5 \%$ felt not hindered. This may be attributed to casual workers who work with oil firm and young school leavers whose ambition is to work in Oil Company and not farming. It was gathered from the survey that this huge percentage of farmers are composed of pensioners who retired from the urban centers such as Lagos, Ibadan, Benin, Asaba, Jos, Port-Harcourt, Sokoto etc.

Apart from the fact that the inhabitants have experienced limited arable land, they also have knowledge of its causes and impact (Table 2). This indicates that all the respondents of the host communities were of two or more opinions of the causes and impact of limited arable land. 100\% of the respondents opined that salinity (salty environment) was one of the major causes of limited arable land, as this does not support the productivity

Table 2. Distribution of farmer opinion on the causes of and impacts of Atlantic Ocean encroachment on limited arable land on the Escravos inhabitants.

\begin{tabular}{|c|c|c|c|c|}
\hline Escravos & Causes & $\%$ & Impacts & $\%$ \\
\hline \multirow{3}{*}{ Ugborodo } & Pollution of land due to Crude oil exploitation & 60 & Scarcity of food Stuff & 40 \\
\hline & Atlantic Ocean encroachment (land degradation). & 100 & Unemployment & 80 \\
\hline & Industrial uses of arable land & 30 & Low productivity of fishes & 50 \\
\hline \multirow{3}{*}{ Otumara } & Atlantic Ocean encroachment (land degradation) & 100 & Migration to urban centers & 60 \\
\hline & Marshy environment. & 30 & Unemployment & 70 \\
\hline & Pollution of land due to Crude oil exploitation & 60 & Scarcity of food stuff & 50 \\
\hline \multirow{3}{*}{ Ugbegungun } & Marshy environment & 30 & Low productivity of fishes & 40 \\
\hline & Atlantic Ocean encroachment (land degradation) & 100 & Scarcity of food stuffs & 60 \\
\hline & Insufficient arable land-size. & 30 & Unemployment & 70 \\
\hline \multirow{3}{*}{ Abiteye } & Pollution of land due to crude oil Exploitation & 80 & Migration to urban centers & 60 \\
\hline & Atlantic Ocean encroachment (land degradation) & 100 & Unemployment & 80 \\
\hline & Salinity & 30 & Scarcity of food stuff & 30 \\
\hline \multirow{3}{*}{ Olobe } & Industrial uses of arable land & 60 & Unemployment & 90 \\
\hline & Atlantic Ocean encroachment (land degradation) & 100 & Low productivity of fishes & 60 \\
\hline & Marshy environment & 30 & High cost of foodstuff & 30 \\
\hline \multirow{3}{*}{ Omadino } & Pollution of land due to crude oil exploitation & 60 & Low productivity of fishes & 60 \\
\hline & Atlantic Ocean encroachment (land degradation) & 100 & Scarcity of food stuffs & 40 \\
\hline & Marshy environment & 30 & Unemployment & 80 \\
\hline \multirow{3}{*}{ Benikrukru } & Atlantic Ocean encroachment (land degradation) & 100 & Migration to urban centers & 60 \\
\hline & Marshy environment & 30 & High cost of foodstuff & 40 \\
\hline & Industrial uses of arable land & 50 & Unemployment & 80 \\
\hline
\end{tabular}

Source: Field survey, (2013). 
of growing arable crops except tree crops like palm tree, coconut tree, mango tree etc., while a mean of $65.0 \%$ of the respondent claimed that pollution of land due to crude oil exploration and exploitation causes limited arable land. This may be attributed to the oil company's exploration and exploitation of crude oil in the area, which resulted in land degradation and alteration of organic matters for plant growth. Thirty percent (30\%) of the respondents also opined that marshy environment contributed to the limited arable land for farming in the area. While $46.67 \%$ mean of the respondent claimed that oil companies occupy the small available arable land either for their operational base or flow stations as lease.

Pollution of land due to crude oil exploration, salinity, marshy environment, industrial uses of arable land interfered with the environment, especially in the area of agricultural activities. These combined together to influence mangrove swamps vegetation cover, environmental degradation and even characteristics. [11] and [12], have individually mentioned one or more of these as causes of limited arable land. Limited arable land according to the inhabitants may cause scarcity of food stuffs, high costs of agricultural products and by-products and low productivity of fishes in the area.

A large percentage of respondents (96.4\%) agreed that they have cordial relationship with their tenants (oil companies). The remaining $4.6 \%$ of the respondents disagree that they have cordial relationship. This may be attributed to those casual workers being drop from work for one reason or the other. Although, majority of the Escravos inhabitants confirmed that the occurrence of environmental degradation causes limited arable land and hence their source of livelihood is thwarted even when those land is generating over $85 \%$ of federal government revenue and $95 \%$ of foreign exchange earnings as reported by [13].

To the communities, government is amorphous and it is the oil company that they see. They therefore vent their anger and frustration on them. They make series of demands as shown in Table 3 from the oil company and failure to meet these demands invariably leads to community incidents which manifest in various ways including shutdown of production facilities, rig blockage and more recently, the expatriate hostages and hijacking

Table 3. Oil company responses to the Escravos inhabitants demands in Warri South-West Local Government Area.

\begin{tabular}{|c|c|c|}
\hline Cause of Agitation & Company Responses & Remarks \\
\hline Demand for employment & $\begin{array}{l}\text { Employment of pensionable staff based on } \\
\text { aptitude, skill and oral test. Engage casual } \\
\text { labour as short term contract staff initiate } \\
\text { youth skill acquisition support program }\end{array}$ & $\begin{array}{l}\text { Host communities want } 60 \% \text { employment } \\
\text { quota Contract jobs are palliatives. Limited } \\
\text { numbers are trained Oil industry is not labour } \\
\text { intensive, hence limited job opportunities. }\end{array}$ \\
\hline $\begin{array}{l}\text { Demand for Amenities/Social } \\
\text { infrastructure }\end{array}$ & $\begin{array}{l}\text { Provision of pipe-borne water, } \\
\text { town halls, and hospital }\end{array}$ & $\begin{array}{l}\text { Companies cannot supply their } \\
\text { basic needs of life }\end{array}$ \\
\hline $\begin{array}{l}\text { Demand for companies } \\
\text { Compensation }\end{array}$ & $\begin{array}{l}\text { Pay compensation for land acquisition, } \\
\text { pollution and damages with percentage } \\
\text { interest demanded by public and government } \\
\text { affairs representatives. No compensation } \\
\text { was paid for sabotage induced spills } \\
\text { or spurious claims. }\end{array}$ & $\begin{array}{l}\text { Compensation provide temporary } \\
\text { income which is hardly invested }\end{array}$ \\
\hline Environmental Degradation & $\begin{array}{l}\text { Better environmental management, e.g } \\
\text { intends to reduce gas flaring, land use. Etc. }\end{array}$ & High cost of environmental management \\
\hline Demand for ex-gratia payment & Resist payment & $\begin{array}{l}\text { Provide temporary income and } \\
\text { encourage unruly behavior }\end{array}$ \\
\hline $\begin{array}{l}\text { Demand for postgraduate } \\
\text { scholarships scheme }\end{array}$ & Resist Approval & $\begin{array}{l}\text { Oil companies believe that on the long-run } \\
\text { the host community will use their human } \\
\text { resources to fight for their right. }\end{array}$ \\
\hline $\begin{array}{c}\text { Demand for agricultural development e.g. } \\
\text { reclamation of arable land, micro credit, } \\
\text { inputs etc }\end{array}$ & Resist assistance & $\begin{array}{l}\text { Chevron/Texaco focus is on oil production } \\
\text { and not agricultural production except Shell } \\
\text { Petroleum Development Camp any }\end{array}$ \\
\hline $\begin{array}{l}\text { Demand for implementation of } \\
\text { understanding (MOU) }\end{array}$ & Resist implementation & \\
\hline $\begin{array}{l}\text { Traditional Demand e.g. Royalty } \\
\text { to the head of host }\end{array}$ & $\begin{array}{l}\text { Laisse 2-Faire, i.e. noninterference } \\
\text { in tradition issues }\end{array}$ & \\
\hline
\end{tabular}

Source: Field Survey, 2013. Note: Each Respondent can give more than one opinion that is why the total for each host community may exceed $100 \%$. 
of boats and helicopters. The operating environment of the coastal area, oil industry in Warri South-West Local Government Area is characterized by inadequate socio-economic facilities, massive unemployment, poverty, impoverished environment, youth restiveness and deep feeling of government neglect. In the absence or near absence of government and the impoverishment nature of the communities, they hold the oil companies as surrogates for government as also reported by [13].

Table 3 shows that the respondents to the various factors responsible for the strained relationship with host communities have largely been inadequate. There are some vital demands from the host communities which are clearly the responsibilities of Oil Companies to fulfill without financial constraint but they resisted, while there are some demands that need joint effort with federal government to fulfill. The identification of some of the social responsibilities of Oil Company to the host communities being observed are as follows:

1) Oil companies are under increasing pressure to support the socio-economic Development of oil producing communities through extensive social investment

2) Programmes as part of their social responsibilities,

3) They must obey the law of the land

4) They must invest fund and train community youths/workers for nature prosperity in providing quality goods and services.

5) They go beyond the law and exercise exemplary achievements in environmental and community progress,

6) Oil Companies are expected to extend their business to include the survival Issues of host communities and other stakeholders.

7) Oil companies are expected to be sensitive to the underdevelopment of host communities and employees.

8) They should be ever ready to assist in providing basic infrastructural facilities, especially in view of the lean resources of government.

9) Therefore, as a result of the hydrocarbon exploration and production activities taking place in the coastal environment communities, expect Oil Company to play a vital role in their development efforts.

\section{Conclusions and Recommendations}

Escravos metropolis in Warri South-West Local Government Area of Delta State, Nigeria, has experienced varying degrees of impacts with regard to limited arable land. It was observed that marshy environment with the spread of mangrove swamps vegetation cover, land environmental degradation, and their interference with the environment, especially in the area of agricultural activities, represent some of the angles from which cause impact emerge. The results also showed that low productivity of fishes, oil bunkering, youth restiveness, scarcity of foodstuffs, high cost of agricultural products and by-products, unemployment and migration to urban centers are the most prominent impacts of limited arable land on Escravos inhabitants. In order to minimize these impacts, the following recommendations are offered for implementation.

Government should review its policy of technological reclamation and reformation of arable land in Escravos metropolis. For instance, Israel government have technological converted her desert land into fertile arable land for farming. Now Israel as a nation is well known in the world today as the highest apple fruits producer. Likewise, our Nigeria government can also follow the trend of technology, by sand-filling the tropical mangrove swamps in Escravos metropolis with fertile soil to become arable land for farming. Oil companies and government agencies should extend inputs distribution outlets to the Escravos inhabitants and should package inputs in smaller units in line with farmer's requirements.

\section{References}

[1] Jones, R.E. (1996) Introduction. In: Joes, G.E., Ed., Infesting in Rural Extension Strategies and Goals, Elsevier Applied Science Publishers, London and New York.

[2] Ofomata, G.E.K. (2001) The Land Resources of Southeastern Nigeria. A Need for Conservation. In: Igbozurike, U.M., Ed., Land Use and Conservation in Nigeria, Nsukka University of Nigeria Press, 94-106.

[3] Okafor, R.C. (2001) Population Pressure, Agricultural Change and Environment Consequences in South Easter Nigeria. The Project on African Agriculture, Working Paper 3, Social Science Research Council, New York.

[4] Eboh, E.C., Obasi, I.N. and Uguru, M.I. (2000) Land Use Pressure and Agricultural Intensification in Anambra State of Nigeria, Implication for Socio-Economic Sustainability of Agricultural Productivity. A Research Submitted to the Social Science Research Council New York, under Their Project on African Agriculture. 
[5] Odu, C.T.I. (2002) Pollution of the Environment by Crude Petroleum. London University Press, London.

[6] Smith, K. (2002) Environmental Hazards Assessing Risks and Reducing Disaster. New York.

[7] Undiandeye, U.C. (2008) Evaluation of the Training and Visit System of Extension of Oyo North Agricultural Development Project (ONADEP), Oyo State, Nigeria. Unpublished PhD Thesis in the Department of Agricultural Extension Services, University of Ibadan, $256 \mathrm{p}$.

[8] Ogboi, E. (2012) Environmental Issues in the Tropics. Solo Press, Agbor, 345 p.

[9] National Population Commission (1991) National Census Result, Delta State Population Statistics. Asaba, Nigeria.

[10] lloeje, N.P. (1992) A New Geography of West Africa. Longman, London.

[11] Lai, K. (1996) Soil Erosion Problems on Altisols in Western Nigeria and Their Control. IITA Monograph, No. 1, Ibadan, Nigeria.

[12] Ajibade, L.T. (2007) Erosion, Deforestation and Industrial Pollution in Kwara State. Kwara State Environmental Protection Agency, Kwara Hotels, Ilorin.

[13] Ojameruaye, E.O. (2009) Corporate Social Responsibilities and Community Development in the Niger Delta. The Community Quarterly Publication of Development, West Shell Petroleum Development of Nigeria Limited. 